\title{
PW03-011 - New Behçet's loci and gene-gene interactions
}

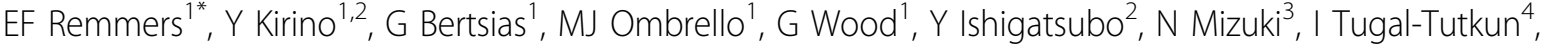 \\ E Seyahi $^{5}$, Y Ozyazgan ${ }^{5}$, DL Kastner ${ }^{1}$, A Gül $^{4}$ \\ From 7th Congress of International Society of Systemic Auto-Inflammatory Diseases (ISSAID) \\ Lausanne, Switerland. 22-26 May 2013
}

\section{Introduction}

We previously identified disease-associated common variants in $I L 10$ and $I L 23 R$, as well as $H L A-B * 51$, in a Behçet's disease (BD) genome-wide association study (GWAS) performed with 311,459 SNPs in 1,215 cases and 1,278 controls from Turkey, but the disease-associated variants in these genes do not fully account for the estimated genetic contribution to disease risk.

\section{Objectives}

To discover novel common BD susceptibility variants and to evaluate disease loci for evidence of gene-gene interactions.

\section{Methods}

We used the Turkish collection GWAS genotypes to impute genotypes of 779,000 markers in the GWAS subjects and then evaluated the imputed markers for disease association. We also searched for new disease associated loci by analyzing patients with uveitis and by specifying different genetic models. We replicated the new BD loci in additional Turkish samples (838 cases, 630 controls) and if polymorphic, in Japanese samples (612 cases, 740 controls). Gene-gene interactions were evaluated by testing the significance of a multiplicative interaction term in a logistic regression model.

\section{Results}

Imputation implicated three new BD susceptibility loci (CCR1, STAT4, and KLRC4). Validation, fine-mapping, and replication confirmed these associations and metaanalyses identified variants with genome-wide significance $\left(\mathrm{p}<5 \times 10^{-8}\right)$ in each. The variants in CCR 1 ,
CC-chemokine receptor 1, and STAT4, signal transducer and activator of transcription 4, were associated with gene expression differences. PBMCs with the diseaseassociated $C C R 1$ variant exhibited reduced migration to the CCR1 ligand, MIP1a. Two disease-associated variants in KLRC4, which encodes an NK receptor family member, encoded missense changes (I29S and N104S). The BD-associated $H L A-B * 51$ haplotype includes $M I C A$, an NK receptor ligand. A statistically significant interaction ( $\mathrm{p}=0.03$ ) was identified between $H L A-B * 51$ (presumably tagging MICA variation) and KLRC4 N104S. Analysis of BD patients with uveitis identified two nonsynonymous variants (D575N and R725Q) in ERAP1 that recessively conferred $\mathrm{BD}$ risk $\left(\mathrm{p}=4.7 \times 10^{-11}\right)$. ERAP1 is an endoplasmic reticulum-expressed aminopeptidase that trims peptides and loads them onto MHC Class I. We found strong evidence for an interaction between the BD-associated Class I allele HLA-B*51 and ERAP1 genotype $\left(\mathrm{p}=9 \times 10^{-4}\right)$.

\section{Conclusion}

This study identified four new genetic loci (CCR1, STAT4, KLRC4, and ERAP1) and two gene-gene interactions (ERAP1 with $H L A-B * 51$ and KLRC4 with HLA$B * 51$, presumably via its LD with $M I C A$ ) that contribute to BD susceptibility. Shared genetic associations of MHC Class I, IL23R, and ERAP1, and the strong interactive effect of the disease-associated Class I allele and ERAP1 support an emerging concept that $\mathrm{BD}$, ankylosing spondylitis, and psoriasis share pathogenic mechanisms.

\section{Disclosure of interest}

None declared.

${ }^{1}$ Inflammatory Dis Section/MGB, NHGRI, Bethesda, USA

Full list of author information is available at the end of the article 


\section{Authors' details}

IInflammatory Dis Section/MGB, NHGRI, Bethesda, USA. ${ }^{2}$ Int Med and Clin

Immunol, Yokahama City University, Yokohama, Japan. ${ }^{3}$ Ophthalmology and Visual Sci, Yokahama City University, Yokohama, Japan. ${ }^{4}$ Istanbul Faculty of Medicine, Istanbul University, Istanbul, Turkey. ${ }^{5}$ Cerrahpaşa Faculty of

Medicine, Istanbul University, Istanbul, Turkey.

Published: 8 November 2013

doi:10.1186/1546-0096-11-S1-A237

Cite this article as: Remmers et al.: PW03-011 - New Behçet's loci and gene-gene interactions. Pediatric Rheumatology 2013 11(Suppl 1):A237.

Submit your next manuscript to BioMed Central and take full advantage of:

- Convenient online submission

- Thorough peer review

- No space constraints or color figure charges

- Immediate publication on acceptance

- Inclusion in PubMed, CAS, Scopus and Google Scholar

- Research which is freely available for redistribution

Submit your manuscript at www.biomedcentral.com/submit 